\title{
Systematic review of the measurement properties of indices of prenatal care utilization
}

\author{
Stewart Rowe ${ }^{1}$, Zahra Karkhaneh ${ }^{1}$, Isaiah MacDonald ', Thane Chambers², Sana Amjad ${ }^{3}$, Alvaro Osornio-Vargas ${ }^{4}$,
} Radha Chari ${ }^{1}$, Manoj Kumar ${ }^{4}$ and Maria B. Ospina ${ }^{1,3,5^{*}}$ (i)

\begin{abstract}
Background: An accurate assessment of the adequacy of prenatal care utilization is critical to inform the relationship between prenatal care and pregnancy outcomes. This systematic review critically appraises the evidence on measurement properties of prenatal care utilization indices and provides recommendations about which index is the most useful for this purpose.

Methods: MEDLINE, EMBASE, CINAHL, and Web of Science were systematically searched from database inception to October 2018 using keywords related to indices of prenatal care utilization. No language restrictions were imposed. Studies were included if they evaluated the reliability, validity, or responsiveness of at least one index of adequacy of prenatal care utilization. We used the COnsensus-based Standards for the selection of health Measurement INstruments (COSMIN) checklist. We conducted an evidence synthesis using predefined criteria to appraise the measurement properties of the indices.

Results: From 2664 studies initially screened, 13 unique studies evaluated the measurement properties of at least one index of prenatal care utilization. Most of the indices of adequacy of prenatal care currently used in research and clinical practice have been evaluated for at least some form of reliability and/or validity. Evidence about the responsiveness to change of these indices is absent from these evaluations. The Adequacy Perinatal Care Utilization Index (APNCUI) and the Kessner Index are supported by moderate evidence regarding their reliability, predictive and concurrent validity.

Conclusion: The scientific literature has not comprehensively reported the measurement properties of commonly used indices of prenatal care utilization, and there is insufficient research to inform the choice of the best index. Lack of strong evidence about which index is the best to measure prenatal care utilization has important implications for tracking health care utilization and for formulating prenatal care recommendations.
\end{abstract}

Keywords: Prenatal care, Pregnancy, Systematic review

\section{Introduction}

Routine prenatal care is a series of regular contacts between a health care provider and a pregnant woman at scheduled intervals that occur between the confirmation of pregnancy and the initiation of labour. The primary goal of these encounters is to deliver effective screening,

\footnotetext{
*Correspondence: mospina@ualberta.ca

${ }^{1}$ Department of Obstetrics \& Gynecology and Medicine, Faculty of Medicine \& Dentistry, University of Alberta, Edmonton, Alberta, Canada

${ }^{3}$ School of Public Health, University of Alberta, Edmonton, Alberta, Canada Full list of author information is available at the end of the article
}

preventive (education), and treatment interventions that seek to improve health outcomes for both the mother and the newborn. Prenatal care also aims to address behavioural risk factors, support women's medical, social and psychological needs, and coordinate actions for labour and delivery [1].

The American College of Obstetrics and Gynecology (ACOG) recommends visiting every 4 weeks for the first 28 weeks of pregnancy followed by bi-weekly visits up to 36 weeks. After 36 weeks, weekly visits are advised [2]. Recommendations about timing of initiation and

(c) The Author(s). 2020 Open Access This article is distributed under the terms of the Creative Commons Attribution 4.0 International License (http://creativecommons.org/licenses/by/4.0/), which permits unrestricted use, distribution, and 
number of routine prenatal care visits for uncomplicated pregnancies differ across jurisdictions, reflecting local contexts, economic, and health policy factors $[3,4]$ and shifting patterns in the schedules for the frequency and interval between prenatal visits [5-7]. Evidence from systematic reviews indicate inconsistencies and lack of consensus on the optimal components of routine prenatal care (i.e., content, frequency and timing of visits) that underlie its effectiveness to avoid adverse outcomes for mothers and their newborns [8].

A variety of methods have been used in past research to determine adequacy of prenatal care in low-risk pregnancies. Over the last two decades, several scoring systems for prenatal care utilization have been developed, each employing different algorithms: the Kessner Index [9], the Kotelchuk Index -also known as Adequacy Perinatal Care Utilization Index (APNCUI)- [10], the Graduated Prenatal Care Utilization Index (GINDEX) [11], the Revised-Graduated Prenatal Care Utilization Index (R-GINDEX) [12], and the US Public Health Service Expert Panel on Prenatal Care (PHS/EPPC) [13]. In general, these indices are founded on two variables: the initiation of prenatal care (i.e., timing of visits related to the weeks of gestation or trimester in which prenatal care is initiated), and the number of prenatal care visits received throughout pregnancy (i.e., frequency). Ultimately, the indices classify prenatal care utilization into distinct categories based on these two variables. Classification of adequacy of prenatal care utilization is likely to be dependent on the index of choice, and misclassifications can potentially lead to systematic differences in the magnitude and direction of the association between prenatal care utilization and maternal and birth outcomes $[12,14,15]$.

The comparability of the different prenatal care utilization indices for low-risk pregnancies has not been completely explored. To date, no systematic review has incorporated a comprehensive analysis of the methods by which prenatal care utilization indices have been developed, nor appraised their relative value. A systematic evaluation of the measurement properties of these indices, their relative strengths and weaknesses, and the quality of the evidence that support their use is an essential step to inform the selection of these indices for research and clinical practice. To fill these knowledge gaps, we completed a systematic review of the scientific literature to assess and compare the measurement properties (i.e., validity, reliability, responsiveness) of prenatal care utilization indices.

\section{Methods}

The systematic review was conducted and reported according to the Preferred Reporting Items for Systematic Reviews and Meta-Analyses (PRISMA) statement [16].
The review protocol was registered with the prospective register of systematic reviews (PROSPERO; registration number CRD42017067110). Comprehensive electronic searches of MEDLINE, EMBASE, CINAHL, and Web of Science were conducted from database inception to October 2018 for studies evaluating the measurement properties of prenatal care utilization indices. An information specialist designed and executed the search strategy using selected subject headings and keywords related to prenatal care utilization indices and measurement properties. The MEDLINE search strategy is available in Additional File 1. In addition, subsequent searches in Google Scholar (for web-based materials) and ProQuest Dissertation and Theses (for unpublished work) were conducted and reference lists of potentially relevant articles were examined. There were no language restrictions imposed on this review.

Indices evaluating prenatal care utilization were defined as quantitative tools that evaluated both the initiation of prenatal care and the frequency at which a pregnant woman attends prenatal care services [12] in low-risk pregnancies. Included in the review were primary studies that evaluated the measurement properties of indices of prenatal care utilization. There were no restrictions on the study design; however, book chapters, editorials, letters, and in vitro or animal studies were excluded.

The search strategy generated a list of articles that two reviewers [IM and SR, or SA and $\mathrm{MO}$ ] screened independently for relevance. Titles and abstracts that were identified as relevant or those that provided insufficient information were pursued for further assessment. The full text of considered articles was again independently reviewed for inclusion [SR, $\mathrm{AO}, \mathrm{RC}, \mathrm{MK}$ and $\mathrm{MO}$ ], with disagreements resolved through consensus. The final reason for the exclusion of an article was documented in the PRISMA flow chart (Fig. 1).

Two reviewers [SR and MO or IM and MO] independently evaluated the methodological quality of studies assessing the measurement properties of indices of adequacy of prenatal care utilization using the COnsensus-based Standards for the Selection of health Measurement INstruments (COSMIN) checklist [17]. Disagreements were again resolved through consensus. The COSMIN checklist was originally developed to inform evidence-based decisions in the selection of patient-reported outcome measures; however, its use has been extended to other measurement domains such as performance-based outcomes. We have selected for this review items from COSMIN that are likely relevant for the evaluation of prenatal care utilization, a construct that fall within the domain of performance-based measure. Therefore, this review evaluates the methodological quality of studies on measurement properties in the following domains: reliability (i.e., internal consistency, reliability), 


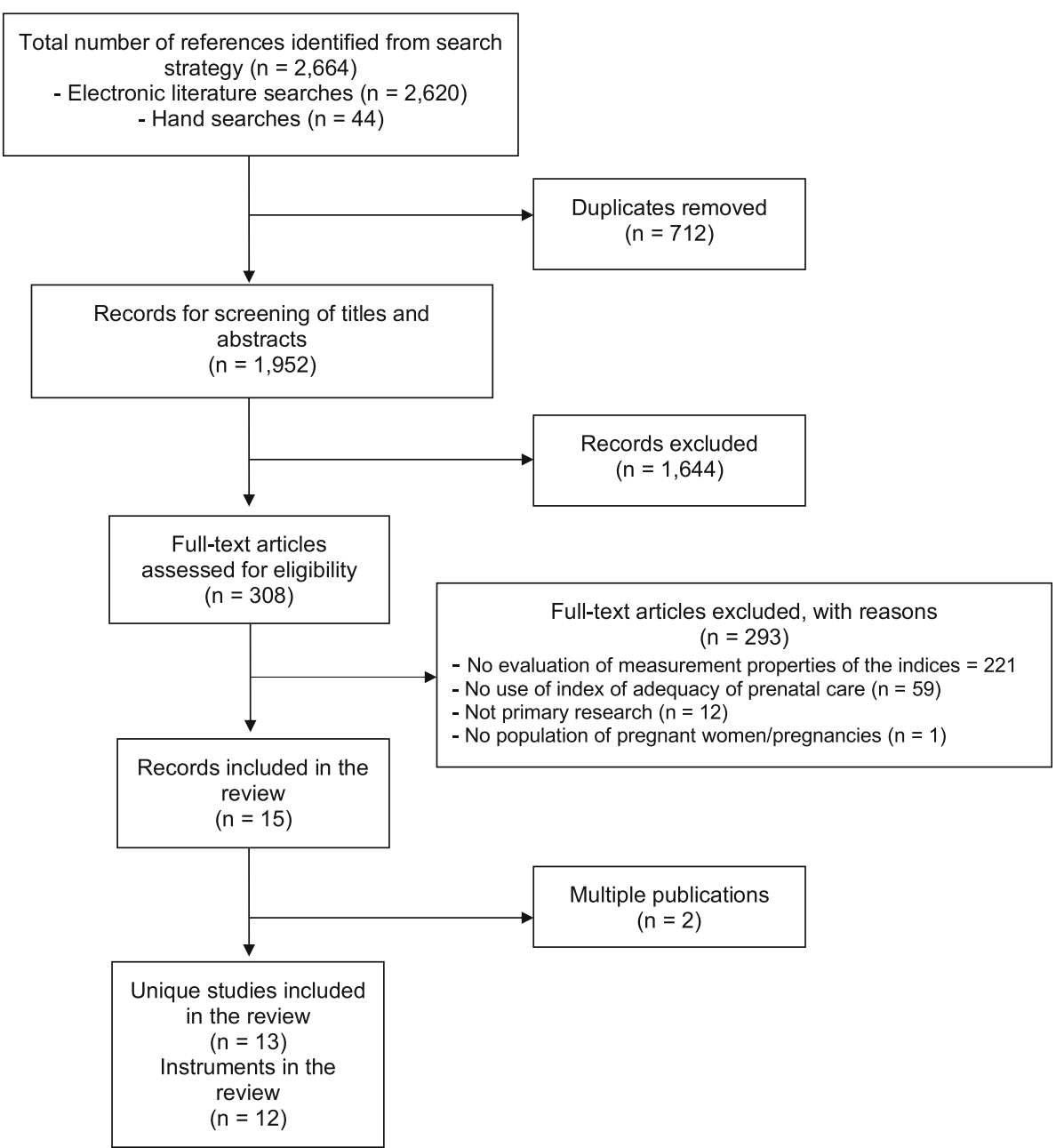

Fig. 1 PRISMA study flow for the review

validity (i.e., content and criterion [predictive and concurrent] validity), and responsiveness (Table 1 ).

The COSMIN checklist is frequently used in systematic reviews of indices and measurement instruments, and it is currently the only validated and standardized tool available for this purpose [17]. For the COSMIN assessment, we extracted information on the measurement properties reported on each study and evaluated the quality of the study methodology. COSMIN contains rules for grading the overall methodological quality of studies reporting measurement properties of instruments. For each measurement property, the COSMIN checklist has 5-18 items covering methodological standards that are rated on a 4-point scale (poor, fair, good, excellent). An overall quality score is obtained by taking the lowest ranking for each item [17].

Table 1 Measurement properties definitions used in the review

\begin{tabular}{|c|c|}
\hline Internal Consistency & Interrelatedness among items. \\
\hline Reliability & $\begin{array}{l}\text { The consistency with which different examiners (inter-rater) or two administrations (test-retest) of a test produce } \\
\text { similar ratings in an instrument. }\end{array}$ \\
\hline Content Validity & Degree to which an instrument includes all the necessary items to represent the concept to be measured. \\
\hline $\begin{array}{l}\text { Criterion-related: Predictive } \\
\text { Validity }\end{array}$ & The extent to which results of a particular instrument compare with an outcome assessed at a later time. \\
\hline $\begin{array}{l}\text { Criterion-related: Concurrent } \\
\text { Validity }\end{array}$ & The degree to which measurement results are an adequate reflection of another assessment/criterion. \\
\hline Responsiveness & The ability of an instrument to detect change over time in the construct to be measured \\
\hline
\end{tabular}


For each index of prenatal care utilization, the overall levels of evidence on each measurement property were synthesized using the data on measurement properties reported in the included studies. If several studies informed the measurement properties of one index, findings were combined based on their number and methodological quality, and the consistency of the results. The level of evidence for the measurement properties of each index was classified according to the following criteria [18]: strong (i.e., consistent findings in multiple studies of good methodological quality or in one study of excellent methodological quality); moderate (i.e., consistent findings in multiple studies of fair methodological quality or in one study of good methodological quality); limited (i.e., one study of fair methodological quality); conflicting (i.e., conflicting findings); and unknown (only studies of poor methodological quality or no studies at all).

Information on authors, publication year, study design, population characteristics, data sources, and measurement properties evaluated in individual studies were first extracted by one reviewer [SR, SA or IM] and verified for accuracy and completeness by a second reviewer [MO]. Discrepancies between data extraction and verification were sorted through consensus.

\section{Results}

The search strategy identified 2664 citations of which 712 duplicates were removed. Titles and abstracts of the remaining 1952 citations were screened for relevance, yielding to 308 articles judged as potentially relevant for the review. After applying the eligibility criteria to the full text of these and examining redundant publications, 13 unique studies were included in the review (Fig. 1). The complete list of excluded studies is available upon request.

The studies were conducted in the United States [10, 12, 14, 19-23], Brazil [24, 25], Belgium [26], Canada [15], and Spain [27]; and published between 1994 and 2014 (median year of publication 2004; interquartile range [IQR] 1996-2013). Sample sizes varied across studies, ranging from 238 to 591,403 participants (median 8957; IQR 725-147,059). Nine studies used a retrospective cohort design [10,12,14,15, 20-23, 25], two were cross-sectional studies $[19,24]$, one was a prospective cohort study [26], and one used a case-control design [27]. Characteristics of the study populations, data sources and indices of prenatal care utilization evaluated in the individual studies are described in Table 2.

A total of 12 indices of prenatal care utilization were evaluated in the studies. The majority of included studies evaluated more than one index (Table 3). The most frequently evaluated index was the APNCUI (evaluated in all the studies included in the review) followed by the Kessner Index (eight studies [10, 12, 14, 21, 22, 24, 25,
27]). Other indices of prenatal care utilization evaluated for their measurement properties were the GINDEX (three studies [12, 14, 25]), its revised version (i.e., RGINDEX; evaluated in two studies $[12,15]$ ) and the PHS/EPPC (two studies [12, 25]). Five studies [20, 2326] evaluated other indices of prenatal care utilization (i.e., Índice IPR/Pré-Natal, Carvalho \& Novaes Index, Ciari Index, Coutinho Index, Content and Timing of Care in Pregnancy, a Cluster solution, and the Last Visit Adequacy of Prenatal Care Index [LV-APNC]). Overall, the methodological quality of studies evaluating the measurement properties of these indices was fair, with more recently published studies having a better quality of reporting. Table 3 summarizes the general characteristics of the included indices of prenatal care utilization and the measurement properties that were evaluated in the individual studies.

\section{Measurement properties and evidence level of the indices of prenatal care utilization}

Reliability of the indices was seldom assessed (two studies $[21,25])$ while validity was the most frequently evaluated measurement property. Predictive validity was evaluated in seven studies [14, 15, 19, 20, 24, 26, 27], while concurrent validity through head-to-head comparisons among indices was evaluated in six studies $[10,12$, 22-25]. The studies did not provide any evidence about the internal consistency, content validity, or responsiveness of any of the 12 indices of adequacy of prenatal care utilization evaluated in this review. An overview of the overall evidence rating for all measurement properties of all indices of prenatal care utilization is provided in Table 4.

Reliability was evaluated for eight indices: the APNCUI [21, 25], the Kessner Index [21, 25], GINDEX [25], PHS/EPPC [25], IPR/Prenatal Index [25], Carvalho \& Novaes Index [25], Ciari Index [25], and Coutinho Index [25]. Moderate evidence was found for good reliability of the APNCUI and the Kessner indices, while limited evidence supported the reliability of the GINDEX, PHS/EPPC, IPR/Prenatal Index, Carvalho \& Novaes Index, and Ciari Index.

Predictive validity was evaluated for the APNCUI [14, $15,19,20,24,26,27]$, the Kessner Index [14, 24, 27], GINDEX [14], R-GINDEX [15], IPR/Prenatal Index [24], Content and Timing of Care in Pregnancy [26], and the LV-APNC [20]. Moderate evidence of predictive validity was found for the APNCUI and the Kessner Index, whereas the evidence was limited for the predictive validity of the GINDEX, R-GINDEX, IPR/Prenatal Index, Content and Timing of Care in Pregnancy and the LV-APNC.

Concurrent validity based on head-to-head comparisons across indices was evaluated for the APNCUI [10, 12, 2225], Kessner Index [10, 12, 22, 24, 25], GINDEX [12, 25], PHS/EPPC [12, 25], IPR/Prenatal Index [24, 25], Carvalho 
Table 2 Characteristics of the studies investigating measurement properties of indices of prenatal care utilization

\begin{tabular}{|c|c|c|c|c|c|c|}
\hline Author, Year & Country & Index & Design & Population and Sample Size & Data Source & $\begin{array}{l}\text { Overall } \\
\text { Quality }\end{array}$ \\
\hline $\begin{array}{l}\text { Alexander, } \\
1996[12]\end{array}$ & USA & $\begin{array}{l}\text { - Kessner } \\
\text { - APNCUI } \\
\text { - GINDEX } \\
\text { - R-GINDEX } \\
\text {-PHS/EPPC }\end{array}$ & $\begin{array}{l}\text { Retrospective } \\
\text { cohort study }\end{array}$ & $\begin{array}{l}\text { Pregnant women having a singleton live birth in South } \\
\text { Carolina } \\
N=169,082\end{array}$ & $\begin{array}{l}\text { Administrative } \\
\text { health database } \\
\text { (1989-1991) }\end{array}$ & Fair \\
\hline $\begin{array}{l}\text { Beeckman, } \\
2013[26]\end{array}$ & Belgium & $\begin{array}{l}- \text { APNCUI } \\
\text { - CTP }\end{array}$ & $\begin{array}{l}\text { Prospective } \\
\text { cohort study }\end{array}$ & $\begin{array}{l}\text { Pregnant women seen at medical centres in Brusssels } \\
\text { Metropolitan Region } \\
N=333\end{array}$ & Interview (2008) & Good \\
\hline $\begin{array}{l}\text { da Silva, } 2013 \\
\text { [24] }\end{array}$ & Brazil & $\begin{array}{l}\text { - Kessner } \\
\text { - APNCUI } \\
\text { - IPR/ } \\
\text { Prenatal } \\
\text { Index }\end{array}$ & $\begin{array}{l}\text { Cross- } \\
\text { sectional } \\
\text { study }\end{array}$ & $\begin{array}{l}\text { Pregnant women seen at primary care services in the } \\
\text { municipality of Joao Pessoa } \\
N=238\end{array}$ & Survey (2010-2011) & Fair \\
\hline $\begin{array}{l}\text { Delgado- } \\
\text { Rodriguez, } \\
1996[27]\end{array}$ & Spain & $\begin{array}{l}\text { - Kessner } \\
\text { - APNCUI }\end{array}$ & $\begin{array}{l}\text { Case-control } \\
\text { study }\end{array}$ & $\begin{array}{l}\text { Pregnant women seen at a University hospital in Granada } \\
N=632\end{array}$ & $\begin{array}{l}\text { Chart review and } \\
\text { interview (1990- } \\
\text { 1993) }\end{array}$ & Fair \\
\hline $\begin{array}{l}\text { Dos Santos, } \\
2013[25]\end{array}$ & Brazil & $\begin{array}{l}\text { - Kessner } \\
\text { - APNCUI } \\
\text { - GINDEX } \\
\text { - PHS/EPPC } \\
\text { - IPR/ } \\
\text { Prenatal } \\
\text { Index } \\
\text { - Carvalho \& } \\
\text { Novaes } \\
\text { Index } \\
\text { - Ciari Index } \\
\text { - Coutinho } \\
\text { Index }\end{array}$ & $\begin{array}{l}\text { Retrospective } \\
\text { cohort study }\end{array}$ & $\begin{array}{l}\text { Pregnant women admitted for delivery at public and } \\
\text { outsourced maternity hospitals in Greater Metropolitan } \\
\text { Vitória } \\
N=1006\end{array}$ & $\begin{array}{l}\text { Chart review and } \\
\text { interview (2010) }\end{array}$ & Fair \\
\hline $\begin{array}{l}\text { Heaman, } 2008 \\
{[15]}\end{array}$ & Canada & $\begin{array}{l}\text { - APNCUI } \\
\text { - R-GINDEX }\end{array}$ & $\begin{array}{l}\text { Retrospective } \\
\text { cohort study }\end{array}$ & $\begin{array}{l}\text { Pregnant women having a hospital-based singleton live } \\
\text { birth in Winnipeg } \\
N=80,989\end{array}$ & $\begin{array}{l}\text { Administrative } \\
\text { health database } \\
\text { (1991-2000) }\end{array}$ & Good \\
\hline $\begin{array}{l}\text { Koroukian, } \\
2002[19]\end{array}$ & USA & - APNCUI & $\begin{array}{l}\text { Cross- } \\
\text { sectional } \\
\text { study }\end{array}$ & $\begin{array}{l}\text { Pregnant women having a singleton live birth in Ohio } \\
N=591,403\end{array}$ & $\begin{array}{l}\text { Administrative } \\
\text { health database } \\
\text { (1993-1996) }\end{array}$ & Fair \\
\hline $\begin{array}{l}\text { Kotelchuck, } \\
1994[10]\end{array}$ & USA & $\begin{array}{l}\text { - Kessner } \\
\text { - APNCUI }\end{array}$ & $\begin{array}{l}\text { Retrospective } \\
\text { cohort study }\end{array}$ & $\begin{array}{l}\text { Women with prenatal care information on the birth } \\
\text { certificate from the } 1980 \text { National Natality Survey } \\
N=9941\end{array}$ & Survey (1980) & Poor \\
\hline $\begin{array}{l}\text { Kurtzman, } \\
2014[20]\end{array}$ & USA & $\begin{array}{l}\text { - APNCUI } \\
\text { - LV-APNC } \\
\text { Index }\end{array}$ & $\begin{array}{l}\text { Retrospective } \\
\text { cohort study }\end{array}$ & $\begin{array}{l}\text { Pregnant women having a singleton live hospital birth in } \\
\text { New York State } \\
N=58,462\end{array}$ & $\begin{array}{l}\text { Perinatal Database } \\
(2007-2011)\end{array}$ & Fair \\
\hline $\begin{array}{l}\text { Penrod, } 2000 \\
{[21]}\end{array}$ & USA & $\begin{array}{l}\text { - Kessner } \\
\text { - APNCUI }\end{array}$ & $\begin{array}{l}\text { Retrospective } \\
\text { cohort study }\end{array}$ & $\begin{array}{l}\text { Women with prenatal care information on the birth } \\
\text { certificate from the } 1980 \text { National Natality Survey } \\
N=7973\end{array}$ & Survey (1980) & Poor \\
\hline $\begin{array}{l}\text { Perloff, } 1997 \\
\text { [22] }\end{array}$ & USA & $\begin{array}{l}\text { - Kessner } \\
\text { - APNCUI }\end{array}$ & $\begin{array}{l}\text { Retrospective } \\
\text { cohort study }\end{array}$ & $\begin{array}{l}\text { Women with birth certificate data from New York city } \\
N=255,884\end{array}$ & $\begin{array}{l}\text { Administrative } \\
\text { health database } \\
\text { (1991-1992) }\end{array}$ & Fair \\
\hline $\begin{array}{l}\text { Rosenberg, } \\
2004[23]\end{array}$ & USA & $\begin{array}{l}\text { - APNCUI } \\
\text { - Cluster } \\
\text { solution }\end{array}$ & $\begin{array}{l}\text { Retrospective } \\
\text { cohort study }\end{array}$ & $\begin{array}{l}\text { Women with live birth data from the } 1988 \text { National } \\
\text { Maternal and Infant Health Survey } \\
N=3544\end{array}$ & Survey (1988) & Good \\
\hline $\begin{array}{l}\text { VanderWeele, } \\
2009[14]\end{array}$ & USA & $\begin{array}{l}\text { - Kessner } \\
\text { - APNCUI } \\
\text { - GINDEX }\end{array}$ & $\begin{array}{l}\text { Retrospective } \\
\text { cohort study }\end{array}$ & $\begin{array}{l}\text { Women with live birth data from the } 2003 \text { National Center } \\
\text { for Health Statistics Linked Birth and Infant Death Cohort } \\
\text { files } \\
N=N R\end{array}$ & $\begin{array}{l}\text { Administrative } \\
\text { health database } \\
\text { (2003) }\end{array}$ & Good \\
\hline
\end{tabular}

APNCUI Adequacy of Prenatal Care Utilization Index, CTP Content and Timing of Care in Pregnancy, GINDEX Graduated Prenatal Care Utilization Index, IPR Infrastructure, process, and results, LV-APNC Last Visit Adequacy of Prenatal Care Index, PHS/EPPC United States Public Health Service Expert Panel on Prenatal Care, R-GINDEX Revised-Graduated Prenatal Care Utilization Index, NR Not reported, USA United States of America 
Table 3 Characteristics of Indices of Prenatal Care Utilization Evaluated for their Measurement Properties

\begin{tabular}{|c|c|c|c|c|c|}
\hline Index and Studies & $\begin{array}{l}\text { Adequate Start of } \\
\text { Prenatal care }\end{array}$ & Adequate Number of Prenatal Visits & $\begin{array}{l}\text { Categories of Prenatal } \\
\text { Care }\end{array}$ & $\begin{array}{l}\text { Basis for } \\
\text { Standard }\end{array}$ & $\begin{array}{l}\text { Properties } \\
\text { Evaluated }\end{array}$ \\
\hline $\begin{array}{l}\text { APNCUI }[10,12,14,15,19- \\
27]\end{array}$ & $1-4 \mathrm{mo}$ & 11 & $\begin{array}{l}\text { Intensive } \\
\text { Adequate } \\
\text { Intermediate } \\
\text { Inadequate } \\
\text { No care/missing }\end{array}$ & ACOG & $\begin{array}{l}\text { - Reliability } \\
\text { - Predictive } \\
\text { validity } \\
\text { - Concurrent } \\
\text { validity }\end{array}$ \\
\hline $\begin{array}{l}\text { Kessner Index }[10,12,14,21, \\
22,24,25,27]\end{array}$ & $1-3 \mathrm{mo}$ & 9 & $\begin{array}{l}\text { Adequate } \\
\text { Intermediate } \\
\text { Inadequate } \\
\text { No care/missing }\end{array}$ & ACOG & $\begin{array}{l}\text { - Reliability } \\
\text { - Predictive } \\
\text { validity } \\
\text { - Concurrent } \\
\text { validity }\end{array}$ \\
\hline GINDEX $[12,14,25]$ & $1-3 \mathrm{mo}$ & 9 & $\begin{array}{l}\text { Intensive } \\
\text { Adequate } \\
\text { Intermediate } \\
\text { Inadequate } \\
\text { No care/missing }\end{array}$ & $\mathrm{ACOG}^{\mathrm{a}}$ & $\begin{array}{l}\text { - Reliability } \\
\text { - Predictive } \\
\text { validity } \\
\text { - Concurrent } \\
\text { validity }\end{array}$ \\
\hline R-GINDEX $[12,15]$ & $1-3 \mathrm{mo}$ & 13 & $\begin{array}{l}\text { Intensive } \\
\text { Adequate } \\
\text { Intermediate } \\
\text { Inadequate } \\
\text { No care } \\
\text { Missing }\end{array}$ & ACOG & $\begin{array}{l}\text { - Predictive } \\
\text { validity }\end{array}$ \\
\hline PHS/EPPC $[12,25]$ & $1-2 \mathrm{mo}$ & 7 (multipara); 9 (primipara) & $\begin{array}{l}\text { Adequate } \\
\text { Intermediate } \\
\text { Inadequate } \\
\text { No care/missing data }\end{array}$ & PHS & $\begin{array}{l}\text { - Reliability } \\
\text { - Concurrent } \\
\text { validity }\end{array}$ \\
\hline IPR/Prenatal Index $[24,25]$ & $1-3 \mathrm{mo}$ & $\geq 6$ & $\begin{array}{l}\text { Adequate } \\
\text { Intermediate } \\
\text { Inadequate }\end{array}$ & & $\begin{array}{l}\text { - Reliability } \\
\text { - Predictive } \\
\text { validity } \\
\text { - Concurrent } \\
\text { validity }\end{array}$ \\
\hline Carvalho \& Novaes Index [25] & $1-3 \mathrm{mo}$ & $\geq 7$ & $\begin{array}{l}\text { Adequate } \\
\text { Inadequate }\end{array}$ & NR & $\begin{array}{l}\text { - Reliability } \\
\text { - Concurrent } \\
\text { validity }\end{array}$ \\
\hline Ciari Index [25] & $1-3 \mathrm{mo}$ & 11 & $\begin{array}{l}\text { Good } \\
\text { Fair } \\
\text { Missing }\end{array}$ & NR & $\begin{array}{l}\text { - Reliability } \\
\text { - Concurrent } \\
\text { validity }\end{array}$ \\
\hline Cluster solution [23] & NR & $\geq 12$ & $\begin{array}{l}\text { Six clusters of patterns } \\
\text { of prenatal care }\end{array}$ & NR & $\begin{array}{l}\text { - Concurrent } \\
\text { validity }\end{array}$ \\
\hline Coutinho Index [25] & $1-3.5 \mathrm{mo}$ & $\geq 6$ & $\begin{array}{l}\text { Adequate } \\
\text { Intermediate } \\
\text { Inadequate }\end{array}$ & NR & $\begin{array}{l}\text { - Reliability } \\
\text { - Concurrent } \\
\text { validity }\end{array}$ \\
\hline $\begin{array}{l}\text { Content and Timing of Care } \\
\text { in Pregnancy [26] }\end{array}$ & $1-4$ mo & $\begin{array}{l}\text { Minimum } 80 \% \text { ratio between visits } \\
\text { conducted and expected visits }\end{array}$ & $\begin{array}{l}\text { Appropriate } \\
\text { Sufficient } \\
\text { Intermediate } \\
\text { Inadequate }\end{array}$ & NR & $\begin{array}{l}\text { - Predictive } \\
\text { validity }\end{array}$ \\
\hline LV-APNC [20] & NR & 9 & $\begin{array}{l}\text { Adequate Plus } \\
\text { Adequate } \\
\text { Intermediate } \\
\text { Inadequate }\end{array}$ & NR & $\begin{array}{l}\text { - Predictive } \\
\text { validity }\end{array}$ \\
\hline
\end{tabular}

ACOG American College of Obstetrics \& Gynecology, IPR Infrastructure, process, and results, LV-APNC Last Visit Adequacy of Prenatal Care Index, mo months ${ }^{a}$ Does not follow full ACOG prenatal care visit recommendation for term and post-term births

\& Novaes Index [25], Ciari Index [25], Coutinho Index [25], and the Cluster solution [23]. Good concurrent validity was supported by moderate evidence for the APNCUI, the Kessner Index, GINDEX, PHS/EPPC, and IPR/Prenatal Index. Limited evidence supported good concurrent validity for the Carvalho \& Novaes Index, the Ciari Index, the Coutinho Index, and the Cluster solution.

\section{Discussion}

This systematic review identified 13 studies that reported on the measurement properties of 12 indices of prenatal care utilization. The APNCUI and the Kessner Index were described the most while others were evaluated in only one or two articles per index, which weakens the level of evidence for the results. We used 
Table 4 Levels of Evidence for the Measurement Properties of Indices of Prenatal Care Utilization

\begin{tabular}{|c|c|c|c|c|c|c|}
\hline Index & $\begin{array}{l}\text { Internal } \\
\text { Consistency }\end{array}$ & Reliability & $\begin{array}{l}\text { Content } \\
\text { Validity }\end{array}$ & $\begin{array}{l}\text { Predictive } \\
\text { Validity }\end{array}$ & $\begin{array}{l}\text { Concurrent } \\
\text { Validity }\end{array}$ & Responsiveness \\
\hline APNCUI & $?$ & ++ & $?$ & ++ & ++ & $?$ \\
\hline Kessner Index & $?$ & ++ & $?$ & ++ & ++ & $?$ \\
\hline GINDEX & $?$ & + & $?$ & + & ++ & $?$ \\
\hline R-GINDEX & $?$ & $?$ & $?$ & + & $?$ & $?$ \\
\hline PHS/EPPC & $?$ & + & $?$ & $?$ & ++ & $?$ \\
\hline IPR/Prenatal Index & $?$ & + & $?$ & + & ++ & $?$ \\
\hline Carvalho \& Novaes Index & $?$ & + & $?$ & $?$ & + & $?$ \\
\hline Ciari Index & $?$ & + & $?$ & $?$ & + & $?$ \\
\hline Cluster solution & $?$ & $?$ & $?$ & $?$ & + & $?$ \\
\hline Coutinho Index & $?$ & + & $?$ & $?$ & + & $?$ \\
\hline Content and Timing of Care in Pregnancy & $?$ & $?$ & $?$ & + & $?$ & $?$ \\
\hline $\begin{array}{l}\text { Last Visit Adequacy of Prenatal Care } \\
\text { Index }\end{array}$ & $?$ & $?$ & $?$ & + & $?$ & $?$ \\
\hline
\end{tabular}

Strong $=+++$; Moderate $=++;$ Limited $=+$; Conflicting + /-; Unknown $=$ ?

the COSMIN checklist to evaluate their methodological quality and the level of evidence informing their uptake. The scientific literature has not comprehensively reported the measurement properties of commonly used indices of prenatal care utilization, and there is insufficient research to inform the choice of the best index. Most of the indices of prenatal care utilization currently used in research and clinical practice have been evaluated for at least some form of reliability and/or validity. Evidence about the responsiveness to change of these indices is absent from these evaluations. The indices of prenatal care utilization supported by the strongest evidence regarding their measurement properties were the APNCUI and the Kessner Index followed by the PHS/ EPPC and the GINDEX. Moderate evidence informs the reliability, predictive and concurrent validity properties of the APNCUI and the Kessner Index. Decisions about their use should be supported on recommendations promoted by local prenatal care clinical practice guidelines (CPG). Both APNCUI and the Kessner Index have similar criteria for optimal timing of initiation of prenatal care (APNCUI 1-4 months; Kessner Index1-3 months) and number of prenatal care visits during pregnancy (APNCUI 11; Kessner Index 9 visits) and seem to align with current CPG recommendations made by ACOG. However, they have different category responses of prenatal care adequacy, with the APNCUI having an extra category of "Intensive" care during pregnancy that the Kessner Index does not consider. The discrepancy within the literature prevents a consensus being formed about the strongest index to measure the adequacy of prenatal care.

The most important strength of this systematic review is the use of the COSMIN taxonomy to evaluate the measurement properties of the proposed indices of prenatal care utilization based on the methodological qualities of the individual studies and the strength of the body of evidence that informs the use of each index. The use of COSMIN by two independent reviewers provided a consistent approach to assess the measurement properties of all indices.

One limitation of this review is that we did not include indirect evidence from studies in which the indices were actually applied either to measure prenatal care utilization as a predictor of pregnancy or birth outcomes, or as an outcome of any other risk factor. One important use of the indices of prenatal care utilization has been to evaluate policy or public interventions seeking to improve the organization and evaluation of prenatal care services. In such situations, the indices can be used to evaluate the changes in levels of prenatal care utilization of such interventions. It is yet to be determined if the utilization of prenatal care services translates into improvements in birth outcomes for the mother and child however, a number of these indices may be useful in examining population utilization levels.

Despite lingering uncertainty of the effectiveness of prenatal care and what adequacy entails, prenatal care has been proposed as a vital strategy to reduce the risk of adverse outcomes at delivery/birth [28]. Several studies have showcased the association between inadequate prenatal care and adverse pregnancy outcomes such as preterm birth, low birth weight, and neonatal death [2933]. Ultimately, the lack of agreement on the best way to measure adequacy of prenatal care has important implications for tracking health care utilization during pregnancy and when formulating recommendations and policies about best practice. 
Additionally, the indices are typically based on visit recommendations for average or low risk pregnancies and do not establish a recommended visit pattern for high risk women or for women with specific medical conditions. This may result in underestimating the prenatal care needs of high risk women and overestimating adequate utilization of prenatal care in the total population [12]. Broader exploration into other components of prenatal care in future research should serve to illuminate the underlining benefits from the care associated with adequate prenatal care.

Prenatal care utilization indices included in this review focus on quantifying the timing and amount of care used and therefore, they do not assess the quality or content of the prenatal services delivered [34]. Because these quantitative indices use data that are routinely collected in administrative health datasets or electronic medical records, they offer a viable alternative to develop audit indicators for quality improvement purposes, and to explore associations between adequacy of prenatal care and pregnancy and birth outcomes at a population level via observational research designs. Other questionnaires have been developed and validated to evaluate the content and quality of prenatal care based on women's satisfaction and values [35]. There is a need to develop theoretically-grounded measures that are able to capture both quantitative and qualitative dimensions of prenatal care utilization and quality. Additional studies evaluating the validity, reliability and responsiveness of measures of prenatal care utilization are needed. A clear reporting of the procedures to measure measurement properties of the indices may facilitate their selection and use for clinical, surveillance, and research purposes.

Differences remain in the scientific literature and in CPG (e.g., ACOG, Society of Obstetricians and Gynaecologists of Canada) regarding recommendations about the timing and the frequency of prenatal care $[1,2]$. However, what is common in these and other CPG is the notion that the frequency of prenatal care visits progressively increases with advancing gestation. Novel developments in screening tests during the first trimester of pregnancy and the notion that important complications that occur later in pregnancy can be predicted in the first trimester have recently reinforced the idea of having more visits at the beginning of pregnancy [36]. Finally, preconception care should be considered part of the spectrum of prenatal care, given that it is likely that many underlying comorbidities are identified prior to pregnancy. This has important implications for stratification of women into high and low risk groupings, which ultimately dictates an adequate frequency of prenatal care for the remainder of their pregnancy [37].

\section{Conclusion}

Most commonly used indices of prenatal care utilization have moderate to limited evidence informing their validity and reliability. Current choices of a preferred index to measure prenatal care utilization can differ depending on the measurement properties that have priority to the users of the index. Important measurement properties such as criterion and predictive validity and responsiveness to change should be further evaluated for all the indices using sound research methodology.

\section{Supplementary information}

Supplementary information accompanies this paper at https://doi.org/10. 1186/s12884-020-2822-5.

Additional file 1. MEDLINE Search Strategy.

\section{Abbreviations}

ACOG: American College of Obstetrics and Gynecology; APNCUI: Adequacy Perinatal Care Utilization Index; COSMIN: COnsensus-based Standards for the selection of health Measurement Instruments; CPG: Clinical Practice Guidelines; GINDEX: Graduated Prenatal Care Utilization Index;

IQR: interquartile range; LV-APNC: Last Visit Adequacy of Prenatal Care Index; PHS/EPPC: US Public Health Service Expert Panel on Prenatal Care; PRISMA: Preferred Reporting Items for Systematic Reviews and MetaAnalyses; R-GINDEX: Revised-Graduated Prenatal Care Utilization Index; SOGC: Society of Obstetricians and Gynaecologists of Canada

\section{Acknowledgments}

Not applicable.

\section{Authors' contributions}

SR performed screening and study eligibility, appraised the risk of bias of individual studies, an contributed to manuscript writing. All authors read and approved the final manuscript. TC designed and executed the search strategy. SR, TC, AO, RC, MK, and MO contributed to study conception and protocol development. SR, ZK, IM, SA, AO, RC, MK and MO contributed with review management, study selection and quality assessment of individual studies included in the review. SR and MO conducted the analysis and synthesis of review. SR and MO drafted the paper and all authors provided critical revisions and contributed to editing of the paper for important intellectual content.

\section{Funding}

Internal institutional funding for Dr. Ospina through the Women and Children's Health Research Institute Recruitment Award. The funding body did not have any role in the design of the study and data collection, analysis or interpretation of data and in writing the manuscript.

\section{Availability of data and materials}

Data sharing is not applicable to this article as no datasets were generated or analysed during the current study.

Ethics approval and consent to participate

Not applicable.

Consent for publication

Not applicable.

\section{Competing interests}

The authors declare that they have no competing interests.

\section{Author details}

${ }^{1}$ Department of Obstetrics \& Gynecology and Medicine, Faculty of Medicine \& Dentistry, University of Alberta, Edmonton, Alberta, Canada. ${ }^{2}$ John W. Scott Health Sciences Library, University of Alberta, Edmonton, Alberta, Canada. 
${ }^{3}$ School of Public Health, University of Alberta, Edmonton, Alberta, Canada. ${ }^{4}$ Department of Pediatrics, Faculty of Medicine \& Dentistry, University of Alberta, Edmonton, Alberta, Canada. ${ }^{5} 220 \mathrm{~B}$ Heritage Medical Research Centre, Edmonton, AB T6G 2S2, Canada.

Received: 21 November 2018 Accepted: 18 February 2020

Published online: 18 March 2020

\section{References}

1. Society of Obstetricians and Gynecologists of Canada. SOGC Clinical Practice Guidelines: Healthy beginnings: Guidelines for care during pregnancy and childbirth. Policy Statement No. 71. 1998. https://sogc.org/wp-content/ uploads/2013/12/gui71EPS9812.pdf.

2. Andresen BS, Knudsen I, Jensen PKA, Rasmussen K, Gregersen N. Two novel nonradioactive polymerase chain reaction-based assays of dried blood spots, genomic DNA, or whole cells for fast, reliable detection of Z and S mutations in the alpha1-antitrypsin gene. Clin Chem. 1992;38(10):2100-7.

3. Omar MA, Schiffman RF. Satisfaction and adequacy of prenatal care utilization among rural low-income women. Outcomes Manag Nurs Pract. 2000;4(2):91-6.

4. Symon A, Pringle J, Downe S, Hundley V, Lee E, Lynn F, et al. Antenatal care trial interventions: a systematic scoping review and taxonomy development of care models. BMC Pregnancy Childbirth. 2017;17(1):8.

5. Dowswell T, Carroli G, Duley L, Gates S, Gulmezoglu AM, Khan-Neelofur D, et al. Alternative versus standard packages of antenatal care for low-risk pregnancy. Cochrane Database Syst Rev. 2015;7:CD000934.

6. Moller AB, Petzold M, Chou D, Say L. Early antenatal care visit: a systematic analysis of regional and global levels and trends of coverage from 1990 to 2013. Lancet Glob Health. 2017;5(10):e977-83.

7. Hanson L, VandeVusse L, Roberts J, Forristal A. A critical appraisal of guidelines for antenatal care: components of care and priorities in prenatal education. J Midwifery Womens Health. 2009;54(6):458-68.

8. Carroli G, Villar J, Piaggio G, Khan-Neelofur D, Gulmezoglu M, Mugford M, et al. WHO systematic review of randomised controlled trials of routine antenatal care. Lancet. 2001;357(9268):1565-70.

9. Gortmaker SL. The effects of prenatal care upon the health of the newborn. Am J Public Health. 1979;69(7):653-69.

10. Kotelchuck M. An evaluation of the Kessner adequacy of prenatal care index and a proposed adequacy of prenatal care utilization index. Am J Public Health. 1994;84(9):1414-20.

11. Alexander GR, Cornely DA. Prenatal care utilization: its measurement and relationship to pregnancy outcome. Am J Prev Med. 1987;3(5):243-53.

12. Alexander GR, Kotelchuck M. Quantifying the adequacy of prenatal care: a comparison of indices. Public Health Rep. 1996;111(5):408-18.

13. Rosen MG, Merkatz IR, Hill JG. Caring for our future: a report by the expert panel on the content of prenatal care. Obstet Gynecol. 1991;77(5):782-7.

14. VanderWeele TJ, Lantos JD, Siddique J, Lauderdale DS. A comparison of four prenatal care indices in birth outcome models: comparable results for predicting small-for-gestational-age outcome but different results for preterm birth or infant mortality. J Clin Epidemiol. 2009;62(4):438-45.

15. Heaman MI, Newburn-Cook C, Green CG, Elliott LJ, Helewa ME. Inadequate prenatal care and its association with adverse pregnancy outcomes: a comparison of indices. BMC Pregnancy Childbirth. 2008;8:15.

16. Moher D, Liberati A, Tetzlaff J, Altman DG. PRISMA group. Preferred reporting items for systematic reviews and meta-analyses: the PRISMA statement. J Clin Epidemiol. 2009;62(10):1006-12.

17. Terwee CB, Mokkink LB, Knol DL, Ostelo RW, Bouter LM, de Vet HC. Rating the methodological quality in systematic reviews of studies on measurement properties: a scoring system for the COSMIN checklist. Qual Life Res. 2012;21 (4):651-7.

18. Mokkink LB, Terwee CB, Patrick DL, Alonso J, Stratford PW, Knol DL, et al. The COSMIN checklist for assessing the methodological quality of studies on measurement properties of health status measurement instruments: an international Delphi study. Qual Life Res. 2010;19(4):539-49.

19. Koroukian SM, Rimm AA. The "adequacy of prenatal care utilization" (APNCU) index to study low birth weight: is the index biased? J Clin Epidemiol. 2002;55(3):296-305.

20. Kurtzman JH, Wasserman EB, Suter BJ, Glantz JC, Dozier AM. Measuring adequacy of prenatal care: does missing visit information matter? Birth. 2014;41(3):254-61.
21. Penrod JR, Lantz PM. Methodological note. Measurement error in prenatal care utilization: evidence of attenuation bias in the estimation of impact on birth weight. Matern Child Health J. 2000;4(1):39-52.

22. Perloff JD, Jaffee KD. Prenatal care utilization in New York City: comparison of measures and assessment of their significance for urban health. Bull N Y Acad Med. 1997;74(1):51-64.

23. Rosenberg D, Handler A, Furner S. A new method for classifying patterns of prenatal care utilization using cluster analysis. Matern Child Health J. 2004; 8(1):19-30.

24. da Silva EP, Lima RT, Costa MJD, Batista M. Development and application of a new index for assessment of prenatal care. Rev Panam Salud Publica. 2013;33(5):356-62.

25. Neto S, Oliveira AE, Zandonade E, Leal MDC. Access to prenatal care: assessment of the adequacy of different indices. Cad Saúde Pública. 2013; 29(8):1664-74

26. Beeckman K, Louckx F, Downe S, Putman K. The relationship between antenatal care and preterm birth: the importance of content of care. Eur J Pub Health. 2013;23(3):366-71.

27. Delgado-Rodriguez M, Gomez-Olmedo M, Bueno-Cavanillas A, Galvez-Vargas R. A comparison of two indices of adequacy of prenatal care utilization. Epidemiology. 1996;7(6):648-50.

28. Fiscella K. Does prenatal care improve birth outcomes? A critical review. Obstet Gynecol. 1995;85(3):468-79.

29. Krueger PM, Scholl TO. Adequacy of prenatal care and pregnancy outcome. J Am Osteopath Assoc. 2000;100(8):485-92.

30. Vintzileos AM, Ananth CV, Smulian JC, Scorza WE, Knuppel RA. The impact of prenatal care on neonatal deaths in the presence and absence of antenatal high-risk conditions. Am J Obstet Gynecol. 2002;186(5):1011-6.

31. Petrou S, Kupek E, Vause S, Maresh M. Antenatal visits and adverse perinatal outcomes: results from a British population-based study. Eur J Obstet Gynecol Reprod Biol. 2003;106(1):40-9.

32. Partridge $\mathrm{S}$, Balayla J, Holcroft CA, Abenhaim HA. Inadequate prenatal care utilization and risks of infant mortality and poor birth outcome: a retrospective analysis of $28,729,765$ U.S. deliveries over 8 years. Am J Perinatol. 2012;29(10):787-93.

33. Debiec KE, Paul KJ, Mitchell CM, Hitti JE. Inadequate prenatal care and risk of preterm delivery among adolescents: a retrospective study over 10 years. Am J Obstet Gynecol. 2010;203(2):122.e1-6.

34. Alexander GR, Kotelchuck M. Assessing the role and effectiveness of prenatal care: history, challenges, and directions for the future. Public Health Rep. 2001;116(4):306-16.

35. Heaman MI, Sword WA, Akhtar-Danesh N, Bradford A, Tough S, Janssen PA, et al. Quality of prenatal care questionnaire: instrument development and testing. BMC Pregnancy Childbirth. 2014;14:188.

36. Nicolaides KH. Turning the pyramid of prenatal care. Fetal Diagn Ther. 2011; 29(3):183-96.

37. Sonek JD, Kagan KO, Nicolaides KH. Inverted pyramid of care. Clin Lab Med. 2016;36(2):305-17.

\section{Publisher's Note}

Springer Nature remains neutral with regard to jurisdictional claims in published maps and institutional affiliations.

\section{Ready to submit your research? Choose BMC and benefit from:}

- fast, convenient online submission

- thorough peer review by experienced researchers in your field

- rapid publication on acceptance

- support for research data, including large and complex data types

- gold Open Access which fosters wider collaboration and increased citations

- maximum visibility for your research: over $100 \mathrm{M}$ website views per year

At BMC, research is always in progress.

Learn more biomedcentral.com/submissions 